\title{
Towards a Unified Approach of Social Justice: Merging Tradition and Modernity in Public Policy Making in India
}

\author{
Subramaniam Chandran
}

\begin{abstract}
This paper explores the social and political imperatives in the sphere of public policy relating to social justice. In India, the colonial legacy and post-colonial social and political pressures sustained the appropriation of 'caste' category in allocating public resources to the backward class of citizens. For several reasons, 'economic' category could not be placed in allocating resources. This paper examines the reasons behind the deliberative exercises and formulating policies and seeks an alternative framework in realizing social justice in terms of a unified category. This attempt can be viewed as a reconciliation of traditional and modern values for a viable alternative in public policy making.
\end{abstract} quota

Keywords—Social justice, caste, public policy, communal

\section{INTRODUCTION}

Coxe OMPETITIVE political mobilization is the usual exercise in Indian politics. Political parties and pressure groups are the vanguard in mobilizing the voters for their own interests which often conflict intra-group interests. Expanding horizon of populist policies is well pronounced in a democratic liberal set up. Fulfilling the interests of competing groups and allocating the adequate resources for those groups are imperative in liberal democracies. Protective discrimination is highly stressed in the concept of social justice. Both justice and equality is conditioned not by philosophical questions but by political and social pressures. The case of India explains these issues. The theme is relevant right from time of the colonial administration.

\section{BRITISH LEGACY}

Tamil Nadu was the composite Madras Presidency during the British rule in India. The British had direct control of administration without intermediary assistance of Rajas or Zamindars. This was in contrast to Northern and Central India where the English had no real control of the administration. In 19th century, Madras Presidency was a much more developed state when compared to other provinces. In late 19th century and early 20th century, in southern India, dams were being constructed and development of modern system of irrigation was in full swing. The modern system of education had already established its roots and people were enlightened about democratic values.

Subramaniam Chandran is with the Vinayaka Missions University, Salem, India (phone: 91-427-3987000, email: s.chandran@rediffmail.com).
In India, varna system and caste groups have their own influence on power structure and allocation of resources. In Madras Presidency, the Brahmins, ritually superior to other castes, appropriated the colonial services for their livelihood. The inequality between the Brahmin and nonBrahmin castes gave rise to social conflict and required policy measures right from the British colonial administration. The British colonial rule had its own interests in meeting the non-Brahmin demands as a means of reducing the hold of Brahmins over the government administrative machinery [1]. The British, who had sought to win over educated Muslims with communal electorates in 1909, apparently calculated that their natural allies in the fluid societies of South India and Bombay were among the dominant landed castes. Through a series of political and administrative actions, they constructed news sets of categories for low ranking castes, which made them eligible for educational, occupational and political privileges that implicitly challenged the legitimacy of the hierarchical order of castes.

The British colonial rule brought certain changes in Tamil social system. The Kingship was abolished, and hence the landlords had new bosses, the British, to please. The British separated the religion from the secular affairs of material world. Hence, in power struggle temples became irrelevant. A quintessential part of the temple system had been that, via the process of endowment, worshippers had kept the god responsible to them. These endowments were temporary to them. These endowments were temporary and remained under the direct control of the donor. Thus the Brahmins were kept pliant to the needs of landlords. The British law declared the temples to be public trusts with absolute rights of ownership and management over the resources with which they were endowed. This gave Brahmans an independent materials base and broke their dependence upon the patronage of politically dominant non-Brahman groups. The British colonial rule also recognized castes on the basis of Varna in a hierarchical order. The cultural privileges of dominant caste groups in relation to the inferior nonBrahman castes were undermined once they too became classified and treated as mere Sudras [2].It was believed that the British also encouraged the groups against the Brahmin monopoly as they were increasingly identified as promoters of anti-colonial sentiments. With support of British governmental, the dominant non-Brahman castes organized, as Justice Party, to resist Brahmans. The sole purpose of the Non-Brahman movement was to restore their earlier privileges with the help of the British.

There are several factors which led to organization of Non-Brahmin movement. The British officials had a lot of mistrust about the Brahmins. The Brahmin's usefulness to the British administration was doubted and the British 
officials saw in them a potential threat to the British supremacy in India. Thus British officials had a desire to curtail the growing influence of Brahmins [3]. The major reason was their affiliation to the Indian National Congress which moved from pro-British to anti-British with a view to attain independence from colonial rule.

\section{COMMUNAL QUOTAS}

In 1920, the Justice party was able to form ministry and maintained its influence till 1937 despite its decline in 1930s. The government ruled by the Justice Party issued a series of Government Orders for the benefit of backward class citizens. First Communal GO (MRO, Public, Ordinary Series, G.O. 613, Sept. 16, 1921) says, "In order to increase the proportion of posts in Government offices held by NonBrahmins, the Government direct that the principle prescribed for the Revenue Department in Board's Standing Order No 128 (2), on the subject of the distribution of the appointments among various castes and communities, should be extended to appointments of all grades in the several departments of the Government.” The Heads of the Department were further instructed to maintain the information of employees according to 6 different communal categories. The Second Communal GO (MRO, Public, Ordinary Series, G.O. 658. Aug. 15, 1922) declared that the government concurred entirely in the desire of the members of the Legislative Council for information on the 6 categories set out in the First Communal GO, not only for new appointments but for all government employees, including personnel in permanent, temporary, or acting appointments, and those appointed either for the first time or promoted.

The Justice party started decaying in mid 20s and most of its leaders joined the Congress. The Justice Party lost power in 1926 and was replaced by an independent ministry supported by the Indian National Congress. Though the Justice Party had lost power, Non-Brahmin movement was still strong through independents and congress, and hence another GO was brought in 1927.

TABLE 1

COMPARTMENTAL RESERVATIONS IN 1927

\begin{tabular}{|l|l|r|}
\hline S. No & \multicolumn{1}{|c|}{ Communal Category } & Reservation \% \\
\hline 1 & Non-Brahmin Hindu & 42 \\
\hline 2 & Brahmins & 17 \\
\hline 3 & Muslims & 17 \\
\hline 4 & Anglo Indians & 17 \\
\hline 5 & Others (including Depressed classes) & 7 \\
\hline
\end{tabular}

The 1927 GO represented a victory for the Vellala, an upper land-owning caste. In these areas, they had provided the leadership of the Justice Party, although there were leaders from other Non-Brahmin castes as well. The Justice Party leaders were drawn from the landed classes and were not much keen on broadening there base by including the landless castes within their ranks. In fact, they began to show a marked disinclination for social reforms and amelioration of the condition of other weaker and backward castes. There was growing discontent among backward Hindus and Depressed classes. The leaders of Backward Classes League wrote to the Executive Council that the appointments reserved for non-Brahmin Hindus all went to a few forward communities. They felt that Communal GO was not giving protection to those who needed it most. They also claimed that the said Communal GO was doing communal injustice to the major part of the population.
Following persistent demand by the Backward Classes League, SCs, and other associations, the Government revised the communal GO in 1947. Another Communal GO was passed in 1947. For the first time Non-Brahmin Backward Hindus were separated from Non-Brahmins Hindus. This bifurcation was done on the basis of the then existing list of backward castes for educational concessions [4].

TABLE 1I

COMPARTMENTAL RESERVATIONS IN 1947

\begin{tabular}{|l|l|r|}
\hline S. No & \multicolumn{1}{|c|}{ Communal Category } & Reservation \% \\
\hline 1 & Non-Brahmin Hindu & 43 \\
\hline 2 & Brahmins & 14 \\
\hline 3 & Muslims & 7 \\
\hline 4 & Anglo Indians & 7 \\
\hline 5 & Scheduled Castes & 14 \\
\hline 6 & Backward Non-Brahmin Hindu & 14 \\
\hline
\end{tabular}

\section{REACTION TO COMMUNAL QUOTAS}

Immediately after the introduction of new Constitution, reactions against the communal system of reservation were visible. Champakam Dorairajan, a Brahmin girl could not get admission in a medical college even though she had scored sufficient marks due to a communal GO issued by the government. The communal GO just distributed seats based on an idea to cap particular communities. So the girl moved the Supreme Court and claimed she had been discriminated only based on her caste, the court agreed and struck down the entire GO. Major agitations broke out in Tamil Nadu leading to political and social upheaval. India had just been formed, the Lok Sabha had not even met, and the government was forced to amend the constitution for the first time, due to the quota situation in the Madras state. The amendment added a clause 4 to Section 15. Clause 4 of Article 15 reads: Nothing in this Article or in Clause 2 of Article 29 shall prevent the state from making any special provision for the advancement of any socially and educationally backward classes of citizens or for the Scheduled Castes and the Scheduled Tribes. After the first amendment, the following reservation scheme was implemented in September 1951.

TABLE III

\begin{tabular}{|l|l|r|}
\hline \multicolumn{3}{|c}{ RESERVATION IN 1951} \\
\hline S. No & \multicolumn{1}{|c|}{ Category } & Reservation \% \\
\hline 1 & Open Competition & 60 \\
\hline 2 & Backward Classes & 25 \\
\hline 3 & Scheduled Castes & 15 \\
\hline
\end{tabular}

\section{EXPANSION OF QUOTAS}

In 1954, the quota for SCs was raised to 16\%. The 1970 report of the Tamil Nadu First Backward Classes (Sattanathan) Commission made several critical observations on the state of reservation in Tamil Nadu. There is a progressive section among the BCs in very many castes; in some castes it is so substantial by all yardsticks that it may as well be regarded as having crossed the borderline. Some castes have taken full advantage of the state's protective measures and made rapid strides, while many others continue to trail behind and are still in the lower stages of stagnancy. It was reported that a group of nine castes accounting for about 11 percent of the BCs population in the state have cornered much of the benefits available to the entire BCs population, namely, 37 percent of the non-gazetted and 48 percent of the gazetted posts, 44 

percent of the engineering and 47 percent of the medical college seats [5].

Such layers of developed segments can very well merge with the advanced sections of society, the so called Forward Classes, and compete openly for careers and opportunities without taking cover under reservations. If the upper crust in each caste is not removed from competing with the less privileged the object of social justice, especially distributive justice, will not be achieved. As a result of the clubbing together of comparatively progressive castes with the most backward classes under one general category, representation of the latter as a group in government services and professional colleges is disproportionately low; without treating them as a separate entity for purposes of reservation there can be no chance of their reaching adequate representation in the foreseeable future, and they will continue to remain depressed.

In keeping with these observations the Commission recommended 16 percent separate reservation for the MBCs and 17 percent reservation for the BCs, taking into consideration its estimate of these categories in the state population as 22 percent and 29 percent respectively; and exclusion from reservation benefits families of salaried persons whose annual income exceeded Rs. 9,000, land owners owning more than ten standard acres, and business people with taxable income exceeding Rs. 9,000.

The DMK ministry, which appointed the Commission in 1969, enhanced in 1971 reservation for the BCs from 25 percent to 31 percent, and for the SCs and STs from 16 percent to 18 percent. However, it did not offer separate reservation for the MBCs; nor did it attempt to eliminate the creamy layer. Disappointed by Government's attitude, Sattanathan urged the Governor to look into the matter.

In 1979, M.G. Ramachandran ministry tried to eliminate creamy layer. For that, it prescribed an annual income limit of Rs. 9,000 on OBC families for eligibility to the reservation benefits. When the G.O. was issued there were protests against its enforcement, and agitations demanding its immediate withdrawal. In the wake of these, and his party's defeat in the January 1980 Lok Sabha elections; MGR announced, on the eve of the dismissal of his ministry, the withdrawal of the G.O., and outwitting his adversaries, also an increase in the reservation for the BCs from 31 percent to 50 percent. These measures amply rewarded the AIADMK in terms of its return to power. They also brought cheer to the vested interests among the BCs and the political parties representing them. Among others, Karunanidhi hailed the announcement as a great success of the agitations launched by his party and the Dravida Kazhagam.

The Supreme Court directed the state government to appoint another commission within two months for reviewing the existing list of $\mathrm{BCs}$ after enumeration and a factual and scientific investigation of their conditions. The government constituted the Tamil Nadu Second Backward Classes Commission under J.A. Ambasanker in 1982. The data collected by the Commission revealed the following: Of the total BC students admitted to professional courses, more than three fourths were from a small number of the BCs accounting for only about two fifths of the BC population in the state; of the total number of $\mathrm{BC}$ scholarships, the total amount of these scholarships, and candidates of all grades selected by the Public Service Commission, about two thirds again went to this relatively small number of BCs; even within this small number, just about one third, accounting for about one third of the total BC population, had cornered as much as two thirds of the $\mathrm{BC}$ admissions to the professional courses and more than half of the scholarships, scholarship amounts, and BC candidates selected by the Public Service Commission.

The report identified the monopoly of some backward castes. The major recommendations of the Chairman of the Ambasankar Commission were as follows [6]:

- Compartmental reservation by grouping the BCs according to the degree of their backwardness, but the commission did not make any suggestion for preventing the 'creaming effect' of reservation by income limit or any other measure.

- Deletion of 34 communities from the existing BC list.

- Inclusion of 29 forward communities in the BC list.

- $\quad$ Reduce the reservation for BCs to $32 \%$ so as to ensure that, in conformity with the court ruling, the total reservation did not exceed 50\% (32\% for BC and $18 \%$ for SC-ST).

The dissenting views of 14 of the 21 members of the Commission made its report controversial right from the time of its submission in February 1985. Among other things, the dissenters questioned the rationale for inclusion in the Chairman's recommendations of 17 forward communities as BCs and deletion of 34 communities from the existing BCs' list. Their demands were, therefore, for retaining the existing list of BCs, with 67 percent reservation, against the much-reduced 32 percent recommended by the Chairman.

Due to controversy, the MGR ministry did not make the report public, and despite repeated requests, did not table it in the Assembly. However, through a series of GOs issued on July 30, 1985, it made selective use of the report. These GOs contain the ministry's orders to continue the existing 50 percent reservation for the BCs (besides 18 percent for the SCs and STs) in both educational institutions and public services; to add 29 communities to the BCs list, without deleting any recommended for deletion; and the continuation of the existing list of MBCs within the BCs' list.

In 1989, the quota was further revised. Out of 50 percent reservation for 201 communities, it set apart 20 percent for 39 MBCs and 68 Denotified Tribes, together accounting for about 31.14 percent of the BCs, and 30 percent for rest of the BCs accounting for about 68.86 percent of the total BC population in the state.

In 1990, the National Front Government announced 27 percent reservations for OBCs in Central services and public sector undertakings. In a resolution passed unanimously in the Assembly on September 30, 1991 the ADMK urged the centre to provide 50 percent reservations to BCs in all its services and educational admissions. Moving the resolution, the Chief Minister, J. Jayalalitha said that the ADMK had been consistently demanding 50 percent reservation at the Centre in both employment and education, and denounced V. P. Singh regime for limiting the reservation only to jobs and only to 27 percent. 
Quota based on the report of the Mandal Commission was resulted in riots and violence in north India. The Supreme Court ruling in Indra Sawhney case restricted overall reservation to 50 percent and asked to eliminate the creamy layer from the notified OBCs. Jayalalitha's relentless campaign since the Supreme Court verdict of November 16, 1992 proclaimed that courts should not hamstrung states in their efforts to render social justice, and in the process portrayed the judiciary as an interloper. In keeping with the views of the ADMK government, in April 1993 the state filed a petition in the Supreme Court, seeking a review of its verdict in the Mandal case. The cabinet views were the state's reservation scheme took into account the real backwardness among various castes and communities; its reservation scheme followed for a long time could not be disturbed without affecting the social fabric, particularly the rights and interests of the BCs; implementation of the Supreme Court's directive that reservation shall not exceed 50 percent would lead to social tension and agitations; and exclusion of the creamy layer would not be judicious as the adoption of any criteria would itself lead to unequal treatment.

In response to a batch of writ petitions against the procedures followed in admissions to professional colleges, while upholding the reservation of 69 percent for the year 1993-94, the Madras High Court ruled that the state had to take steps to implement the Supreme Court's orders in the right perspective and see that reservation was brought down to 50 percent at least before the next academic year. However, in response to a writ petition from the Voice (Consumer Care) Council, the Supreme Court restrained the state from exceeding 50 percent even for 1993-94.

However, Jayalalitha introduced a Bill to give effect to the aspirations of the vast majority of the people of Tamil Nadu so as to achieve the goal of social justice. The Bill reiterated the continuance of the existing 69 percent reservation, was unanimously passed. Moreover, she demanded President's assent to the Bill. Political parties also supported her claim sought protection for 69 percent. As a result, the Tamil Nadu Reservation Bill obtained President's assent and the Constitution (85th) Amendment Bill was passed unanimously by the Parliament and was included in the Ninth Schedule under Article 31B.

TABLE IV

PRESENT DAY QUOTA IN TAMIL NADU

\begin{tabular}{|l|l|r|r|}
\hline $\begin{array}{l}\text { S. } \\
\text { No }\end{array}$ & Category & $\begin{array}{l}\text { Population \% } \\
(2001)\end{array}$ & Reservation \% \\
\hline 1 & Backward classes & 46.14 & 30 \\
\hline 2 & $\begin{array}{l}\text { Most Backward } \\
\text { classes }\end{array}$ & 17.43 & 20 \\
\hline 3 & $\begin{array}{l}\text { Denotified } \\
\text { Communities }\end{array}$ & 3.44 & 18 \\
\hline 4 & Scheduled Castes & 19.00 & 1 \\
\hline 5 & Scheduled Tribes & 1.04 & - \\
\hline 6 & Others & 12.95 & 69 \\
\hline & Total & 100 & \\
\hline
\end{tabular}

\section{UNIFIED APPROACH TO SOCIAL JUSTICE}

The concept of social justice and its perception by the state and the society have significance evolutionary path in India. In ancient times, the monarchical state comfortably relied on Dharmasastras to execute social justice. It implies the very ethical basis of the organization and function of the state. The medieval state witnessed an addition of Islamic texts in executing social justice. A parallel perception of social justice was happened among monarchical states, perhaps, with conflict of interests. A transition from 'varna' to 'religion' was happened with sufficient justification based on religious texts. During this process, social stratification accommodated more divisions. In modern era, the colonial rule of the British appropriated the social stratification either for the convenience of administration or for sustaining their domination. The colonial state ignored the ethical values attached to social stratification, but saw the relative deprivation and dormant social conflict. The perception of social justice in terms of contextual status was resulted in the initiation of protective discrimination based on caste system. The census initiated by the British in 1881 recorded the caste data until 1931. The discontinuity occurred due to the views expressed by the social reformers that the caste system was considered to be a retrograde and not based on the principle of social equality.In India, especially in south India, for the past one hundred years social and political discourse is much dominated by disadvantaged groups in reaction to nationalist as well as conventionalist. One way or other, this trend was encouraged by colonial rulers themselves. Disadvantaged social groups began to counter the nationalist discourse. One can come across three types of studies on the category of social identity relating to various appropriations. These include anthropological or cultural orientations [7], political mobilization [8], and social justice or the policy of reservation [9].The policy of reservation for backward classes is still debated in terms of its philosophy of justice. There is need to establish justice for different groups of citizens. It implies that there is need for a unified approach for social justice. The unified approach incorporates both traditional and modern categories. It also tries to bring the hitherto dissatisfied groups into the fold of social justice. Framing of social justice index is important on the one hand and seeking consensus for the index from the political parties, pressure groups and citizens at large is on the other hand [10].

The unified approach combines different categories to distribute the level of scores so as to establish just affirmations. It also includes the category of caste as a determinant but not as only determinant. Besides, it covers all citizens for affirmative action irrespective of the socalled backwardness. In other words, the real backward citizens will score higher than the forward citizens in terms of social, economic and educational criteria. This system automatically eliminates the creamy layers and includes the real poor and backward citizens from the so-called nonbackward category of class.

As the table shows the citizen who is on the lower level of social strata will score more. Thus, the social justice index signifies higher score for the backward citizens and low score for the upper class. Interestingly, the higher score is set as double the low score. It implies that the backward citizen is given double points. It applies not only to caste but also to education and income categories. The recent effort of the government to conduct caste-wise census will unravel the mysteries associated with the percentage of social stratification and allocation of resources. 
World Academy of Science, Engineering and Technology

International Journal of Social, Behavioral, Educational, Economic, Business and Industrial Engineering Vol:5, No:5, 2011
[5]. These castes were Agamudayan/ Thuluva Vellalars; Devanga/

TABLE V

\begin{tabular}{|c|c|c|}
\hline Class & Category & Affirmative Score \\
\hline \multirow{4}{*}{ Community/Class } & $\mathrm{SC}$ & 6 \\
\hline & ST & 6 \\
\hline & $\mathrm{OBC}$ & 5 \\
\hline & $\mathrm{OC}$ & 3 \\
\hline \multirow{2}{*}{ Sex } & Female & 4 \\
\hline & Male & 3 \\
\hline \multirow{3}{*}{ Education (Mother) } & Illiterate & 4 \\
\hline & School & 3 \\
\hline & Graduate & 2 \\
\hline \multirow{3}{*}{ Education (Father) } & Illiterate & 4 \\
\hline & School & 3 \\
\hline & Graduate & 2 \\
\hline \multirow{4}{*}{ Employment (Mother) } & Unemployed & 5 \\
\hline & Low level & 4 \\
\hline & Middle level & 3 \\
\hline & Upper level & 2 \\
\hline \multirow{4}{*}{ Employment (Father) } & Unemployed & 5 \\
\hline & Low level & 4 \\
\hline & Middle level & 3 \\
\hline & Upper level & 2 \\
\hline \multirow{4}{*}{ Annual income } & Below 24000 & 5 \\
\hline & $24001-50000$ & 4 \\
\hline & $50001-100000$ & 3 \\
\hline & Above 100001 & 2 \\
\hline \multirow{4}{*}{$\begin{array}{l}\text { Special points } \\
\text { (physically } \\
\text { challenged, widows, } \\
\text { ex-servicemen) }\end{array}$} & SC & 6 \\
\hline & ST & 6 \\
\hline & OBC & 4 \\
\hline & $\mathrm{OC}$ & 3 \\
\hline
\end{tabular}

\section{CONCLUSION}

This paper explores socio and political imperatives in the sphere of public policy relating to social justice measures. In India, the colonial legacy and post-colonial social and political pressures sustained the appropriation of 'caste' category in allocating public resources to the backward class of citizens. For several reasons, 'economic' category could not be placed in allocating resources. This paper examines the reasons behind the deliberative exercises and formulating policies and seeks an alternative framework in realizing social justice in terms of a unified category. This attempt can be viewed as a reconciliation of traditional and modern values for a viable alternative in public policy making. The social justice index suggests a unified approach in deciding affirmative actions for the backward class of citizens. Implementation of this unified system requires an understanding of its philosophy and demands the consensus among citizens, policy makers and political parties and pressure groups.

\section{REFERENCES}

[1]. R. Caldwell, A Comparative Grammar of the Dravidian or SouthIndian Family of Languages, London: Harrison, 1998; P. Rajaraman, The Justice Party: A Historical Perspective 1916-37, Madras: Poompzhil Publishers, 1988; M.R. Barnett, The Politics of Cultural Nationalism, Princeton: Princeton University Press, 1976; Nambi Aarooran, Tamil Renaissance and Dravidian Nationalism, 1916-1944, Madurai: Koodal Publishers, 1980; A.N. Sattanathan, "The Dravidian movement in Tamil Nadu and its legacy," lectures delivered at the University of Madras in 1981.

[2]. E.F. Irachick, Politics and social conflicts in south India: The NonBrahmin movement and Tamil Separatism, 1916-1929, Oxford University Press, 1969.

[3]. R.L. Hardgrave, Jr. The Dravidian Movement, Bombay: Popular Prakashan, 1965.

[4]. S. Chandran, Tamizhaga Arasiyal, Chennai: Bharathi Puthakalayam, 2001 Sedan; Gavara; Illuvan/Ezhuvan/ Illathar; Kaikolan/Sengunthar; Sadhu Chetty; Saurashtra; Vadugan; and Virakodi Vellala

[6]. Report of the (Second) Backward class commission, Government of Tamil Nadu, 1984.

[7]. L. Dumont, Homo Hierarchicus: The Caste System and Its Implications, Delhi: Oxford University Press, 1988; G.S. Ghurye, Caste and Race in India, Bombay: Popular Prakashan, 1964; J.H. Hutton, Caste in India: Its Nature, Function and Origin, Bombay: Oxford University Press, 1961.

[8]. R. Kothari, ed. Caste in Indian Politics, Delhi: Orient Longman, 1970; M.N. Srinivas, Caste in Modern India, Bombay: Asia Publishing House, 1964.

[9]. Marc Galanter, Competing Equalities: Law and the Backward Classes in India. New Delhi: Oxford University Press, 1984; A. Beteille, The Backward Classes in Contemporary India, Delhi: Oxford University Press, 1992; G. Mahajan, Democracy, Difference and Social Justice, Delhi: Oxford University Press, 1998; P. Radhakrishnan, P. "Backward Class Movements in Tamil Nadu,” in M.N. Srinivas ed. Caste: Its Twentieth Century Avatar, Delhi: Viking, 1996.

[10]. S. Chandran, Indhya Arasiyal, Bharathi Puthakalayam, Chennai, 2003.

Dr. Subramaniam Chandran teaches at Vinayaka Missions University. He gained M.A. degree in Political Philosophy and Ph.D. degree in Politics and Public Administration at the University of Madras. He has authored books in the field of history, political science and public administration. Currently, he is preparing instructional design for mobile learners. He is also a recipient of best book award given by the Government of Tamil Nadu. 